\title{
Atmospheric sub-3 nm particles at high altitudes
}

\author{
S. Mirme ${ }^{1}$, A. Mirme ${ }^{1}$, A. Minikin ${ }^{2}$, A. Petzold ${ }^{2}$, U. Hõrrak ${ }^{1}$, V. -M. Kerminen ${ }^{3}$, and M. Kulmala ${ }^{4}$ \\ ${ }^{1}$ Institute of Physics, University of Tartu, Ülikooli 18, 50090, Tartu, Estonia \\ ${ }^{2}$ Deutsches Zentrum für Luft- und Raumfahrt (DLR), Institut für Physik der Atmosphäre, Oberpfaffenhofen, Germany \\ ${ }^{3}$ Finnish Meteorological Institute, P.O. Box 503, 00101, Helsinki, Finland \\ ${ }^{4}$ Department of Physics, University of Helsinki, P.O. Box 64, 00014, Helsinki, Finland
}

Received: 23 August 2009 - Published in Atmos. Chem. Phys. Discuss.: 17 September 2009

Revised: 21 December 2009 - Accepted: 4 January 2010 - Published: 19 January 2010

\begin{abstract}
Formation of new atmospheric aerosol particles is known to occur almost all over the world and the importance of these particles to climate and air quality has been recognized. Recently, it was found that atmospheric aerosol particle formation begins at the diameter of around 1.5-2.0 nm and a pool of sub- $3 \mathrm{~nm}$ atmospheric particles - consisting of both charged and uncharged ones - was observed at the ground level. Here, we report on the first airborne observations of the pool of sub- $3 \mathrm{~nm}$ neutral atmospheric particles. Between 2 and $3 \mathrm{~nm}$, their concentration is roughly two orders of magnitude larger than that of the ion clusters, depending slightly on the altitude. Our findings indicate that new particle formation takes place throughout the tropospheric column up to the tropopause. Particles were found to be formed via neutral pathways in the boundary layer, and there was no sign of an increasing role by ion-induced nucleation toward the upper troposphere. Clouds, while acting as a source of sub- $10 \mathrm{~nm}$ ions, did not perturb the overall budget of atmospheric clusters or particles.
\end{abstract}

\section{Introduction}

The influence of aerosol particles on cloud radiative properties and precipitation patterns constitutes one of the biggest challenges in developing models that simulate the behaviour of the Earth's climate system (Lohman and Feichter, 2005; Baker and Peter, 2008; Rosenfeld et al., 2008; Koren et al., 2008). A potentially important yet poorly quantified source of cloud nucleating particles is atmospheric aerosol formation (Spracklen et al., 2008; Pierce and Adams, 2009; Wang and Penner, 2009; Makkonen et al., 2009). This process involves the nucleation of tiny particles, or clusters, from

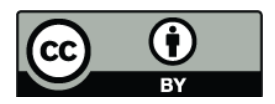

Correspondence to: S. Mirme (sander.mirme@ut.ee) gaseous precursor vapours and the subsequent growth of these clusters to larger sizes. Observations confirm that atmospheric aerosol particle formation is a frequent phenomenon that takes place in a wide variety of locations both on ground and in the free troposphere (Kulmala et al., 2004; Kulmala and Kerminen, 2008; O'Dowd et al., 2007, 2009).

Proposed atmospheric nucleation mechanisms include kinetic (or barrierless) nucleation, binary and ternary homogeneous nucleation, ion-induced (or ion-mediated) nucleation, as well as activation of stable neutral or charged clusters (Kulmala and Kerminen, 2008; Yu et al., 2008). Recently, it was demonstrated that atmospheric nucleation is initiated at sizes (particle mobility diameter) of $1.5-2.0 \mathrm{~nm}$ in continental boundary layers, and that this process is tied strongly with the existence of sub- $3 \mathrm{~nm}$ pool of neutral clusters (Kulmala et al., 2007; Sipilä et al., 2008). Understanding the behavior of such clusters in different atmospheric compartments is crucial when quantifying the relative role of various nucleation mechanisms and their contribution to the population of cloud condensation nuclei.

Aerosol particle formation in the free troposphere (FT) is of central interest for several reasons. First of all, the FT has a very large volume and it is connected with many cloud systems. Secondly, the general conditions of the FT, including low temperatures and pre-existing aerosol concentrations as well as high ionization rates, are thought to favour nucleation there (Yu et al., 2008; Kazil et al., 2008). Thirdly, due to their lower sinks compared with the boundary layer aerosol particles, nucleated particles have a relatively long residence times in the FT, giving them time to grow in size. Finally, aerosols formed in the FT may be entrained into the boundary layer, raising aerosol concentrations especially in remote areas of the world (Raes, 1995; Korhonen et al., 2008). Our understanding on FT nucleation relies heavily on modelling studies that have concentrated on either binary water-sulphuric acid or ion-induced nucleation (Yu et al., 2008; Brock et al., 1995; Laaksonen et al., 2000; Ekman et

Published by Copernicus Publications on behalf of the European Geosciences Union. 
al., 2008; Kazil and Lovejoy, 2004; Kanawade and Tripathi, 2006). In a small number of studies the number concentrations of ultrafine $(>3-5 \mathrm{~nm}$ ) aerosol particles have been measured in the FT, with main emphasis put on the upper parts of the FT (Clarke, 1993; de Reus et al., 2000; Twohy et al., 2002; Benson et al., 2008; Weigelt et al., 2009; Young et al., 2007). Very few measurements of ion cluster size distributions from this region are available (Arnold, 2006), and observations of neutral clusters are entirely lacking.

Here we provide clear experimental evidence for the existence of neutral clusters in the whole atmospheric column up to the tropopause. The observed atmospheric clusters include stable clusters, dynamic clusters (dynamically forming and evaporating) and also big molecules due to observational techniques used. However, the number of big molecules can be estimated to be minor compared to the total number of clusters in the diameter size range of $2-3 \mathrm{~nm}$. Also later in this paper we call sub- $3 \mathrm{~nm}$ particles as atmospheric clusters, and particles bigger than $3 \mathrm{~nm}$ we call particles. Our data are based on measurements made using a neutral cluster and air ion spectrometer (NAIS). The NAIS is an instrument that measures the distribution of naturally charged particles (ions) in the electric mobility range from 3.2 to $0.0013 \mathrm{~cm}^{2} \mathrm{~V}^{-1} \mathrm{~s}^{-1}$ and the distribution of aerosol particles in the mobility equivalent diameter range from 1.5 to $40 \mathrm{~nm}$. In 2008, a new version of the instrument was built that is capable of airborne measurements. In May 2008, the NAIS was installed in the DLR Falcon 20 for the EUCAARI-LONGREX (European Integrated project on Aerosol Cloud Climate and Air Quality Interactions (Kulmala et al., 2009)/Long-range Experiment) campaign. Data was collected from about 50 flight hours in total.

The principal goals of this paper are i) to demonstrate the capability of Airborne NAIS to measure neutral sub$3 \mathrm{~nm}$ clusters in the free troposphere, ii) to find out how the concentrations and size distributions neutral and charged clusters vary with altitude and how these quantities depend on the presence of cloud, and iii) to get observational insight into the contribution of ion-induced nucleation to freetropospheric aerosol particle formation. We will also discuss which implications our findings will have on future studies on aerosol sources in the free troposphere.

\section{Materials and methods}

\subsection{Neutral Cluster - Air Ion Spectrometer (NAIS)}

The NAIS is an instrument that measures the distribution of naturally charged particles (ions) in the electric mobility range from 3.16 to $0.0013 \mathrm{~cm}^{2} \mathrm{~V}^{-1} \mathrm{~s}^{-1}(0.8$ to $42 \mathrm{~nm})$ and the distribution of aerosol particles in the mobility equivalent diameter range from 1.5 to $42 \mathrm{~nm}$. It is a successor to the Air Ion Spectrometer (AIS, Airel Ltd., Estonia) (Mirme et al., 2007). The spectrometer has been used successfully in studying atmospheric particle nucleation all over the world (Kulmala et al., 2007).

The principal parts of the spectrometers are two cylindrical aspiration type differential mobility analyzers (DMAs): one for positive and one for negative ions. In each analyzer the sampled ions are simultaneously collected on 21 electrometer rings in 21 electrical mobility fractions. The NAIS also includes unipolar corona chargers with charger ion traps to allow the measurement of uncharged particles. The particle charging probabilities are estimated from Fuchs' theory (Fuchs and Sutugin, 1971). The lower detection limit of the NAIS is determined by the charging probabilities, cluster concentration and the charger ion masses and mobilities. The charger ion mobilities from 1.3 to $1.6 \mathrm{~cm}^{2} \mathrm{~V}^{-1} \mathrm{~s}^{-1}$ define the limit for the lowest detectable size, which is approximately $2 \mathrm{~nm}$ (Asmi et al., 2009). Particles below this limit cannot be reliably distinguished from the charger ions.

At normal atmospheric pressure the sample and sheath flows of the analyzers are $0.51 \mathrm{~s}^{-1}$ and $11 \mathrm{~s}^{-1}$, respectively. A closed loop sheath flow arrangement is used in both analyzers. The noise and the offset signal of the electrometers are measured by sampling through an additional filter consisting of a unipolar corona charger and an electrostatic filter, which removes any particles from the air sample that could be detected by the analyzer. Similar filtration is used also for cleaning the re-circulated sheath air.

\subsection{Airborne NAIS}

We developed a new version of NAIS, which is able to measure ambient air at varying altitudes while being situated inside a pressurized aircraft. The particle size range of the new instrument is kept invariant of air pressure and temperature changes. This is achieved by automatic adjustment of the sheath airflows (see Fig. 1) to compensate for the variability of the particle mobility due to changes in the air pressure and temperature (see Sect. "Controlling the DMA flow-rates"). The effect of temperature variations is considered small because of warming in the sampling line. The sample air volume flow-rate is automatically kept constant.

The data acquisition system was replaced to enable the new airflow control mechanisms and to increase the measurement frequency of the instrument channels by an order of magnitude. This allows us to use better data processing methods and acquire reliable 1-minute-average spectra in noisy and low signal conditions.

Similarly to older NAIS instruments, the variation in particle charging efficiency due to variation of charger ion mobility is compensated by keeping the electric current that crosses the charger volume constant. The current is proportional to charger ion concentration $n$ and the ion mobility $z_{c h}$. Together with the constant volume flow rate, this maintains the efficiency of diffusion charging, which is described by the product of charger ion mean mobility, their concentration 


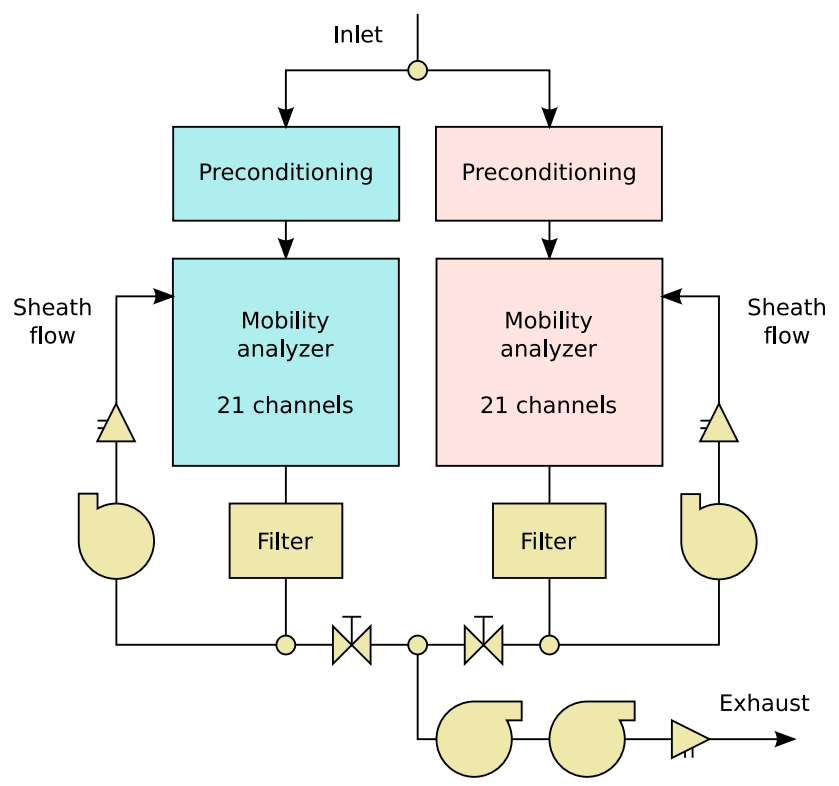

Fig. 1. The airflow system of the NAIS used for airborne measurements.

and the charging time $t$ (the $z_{c h} n t$ product). The variation of electric field inside the charger is considered small.

The automatic adjustment of the particle size classification, sample flow rate and charging efficiency mean that all the principal parameters of the DMA are kept constant, so that the same data inversion procedure can be used regardless of changes in the air pressure.

These changes also benefit ground-based measurements. Due to the automatic flow control, the instrument will be less affected by pollution of the air tract and related changes in flow system efficiency. The new data acquisition system allows to better control the particle chargers and filters.

\subsection{Controlling the DMA flow-rates}

The limiting mobility $z$ of a DMA is a function of the capacitance $C_{a n}$ and voltage of the analyzer $U_{a n}$, which always remain constant in the NAIS, and volume flowrate $Q$, which can be varied (Tammet, 1970) ( $\varepsilon_{0}$ is the vacuum permittivity).

$z=\frac{\varepsilon_{0} Q}{C_{a n} U_{a n}}$

The size of the classified particle is invariant of air pressure if $Q$ is chosen so that the expression $\frac{Q}{z}$ remains invariant of air pressure.

The NAIS uses venturi flowmeters, which express the flow rate as a pressure difference $\Delta p$ (Eq. 2). This is in turn measured by differential pressure sensors. The real pressure difference is additionally affected by air density $\rho=\frac{P}{R T}$ (where $P$ is air pressure, $R$ is gas constant and $T$ is temperature), discharge coefficient $C$, area of the venturi inlet $A_{a}$ and area of the venturi neck $A_{b}$.

$$
\begin{aligned}
& \Delta p=Q^{2} \frac{P}{R T} \cdot \frac{1}{2 C^{2}} \cdot \frac{A_{a}^{2}-A_{b}^{2}}{A_{a}^{2} A_{b}^{2}} \\
& Q=C \sqrt{\frac{R T}{P}} \sqrt{2 \Delta p} \frac{A_{a} A_{b}}{\sqrt{A_{a}^{2}-A_{b}^{2}}}
\end{aligned}
$$

The relation between particle radius $r$, mobility and air pressure can be found from the Millikan equation (Fuchs, 1964):

$z_{\text {Millikan }}=e \frac{1+\frac{l}{r}\left[a+b \exp \left(-c \frac{r}{l}\right)\right]}{6 \pi \eta r}$

where $a, b$ and $c$ are empirical constants, $e$ is the elementary charge, $l$ is the particle mean free path and $\eta$ is the viscosity of air.

In case of small particles, for which the mean free path is much larger than particle radius, Eq. (4) can be simplified (Tammet, 1995). After substituting $l$ and $\eta$, we get the Eq. (5):

$\lim _{r \rightarrow 0} z_{\text {Millikan }}=\frac{e(a+b)}{6 \pi r^{2}} \frac{1.256}{P} \sqrt{\frac{k T}{m_{g}}}$

where $m_{g}$ is the mass of air molecule.

So $\frac{Q}{z}$ remains constant if $\Delta p \cdot P$ product is kept constant:

$\frac{Q}{z} \propto \frac{\sqrt{\frac{T \cdot \Delta P}{P}}}{\frac{\sqrt{T}}{P}}=\sqrt{\Delta P \cdot P}$

\subsection{Operation on-board the aircraft}

The Airborne NAIS flew on-board the DLR Falcon 20 aircraft in total of 48.5 flight hours during the EUCAARILONGREX campaign in May 2008.

We used a sample air inlet with about $30 \mathrm{~mm}$ of inner diameter facing forward in flight direction. Inside the aircraft we had a valve that made it possible to close the inlet completely. The instrument was connected to the inlet by about $1 \mathrm{~m}$ of tube with $\sim 30 \mathrm{~mm}$ inner diameter (Fig. 2). The inlet losses, while unknown, are expected to be not very high due to the very high sampling flow rate of $11 \mathrm{~s}^{-1}$.

Variations of the ramp pressure on the inlet exceeded the maximum pressure created by the sample flow blowers. This made it necessary to manually adjust a valve on the outlet to keep the correct sample flow rate.

During the campaign we added a cone with a 6-mm diameter hole in front of the pipe to reduce the effect of ramp pressure while gradually slowing down the air without creating turbulence. This decreased measurement noise and made the manual flow rate adjustment less critical. 


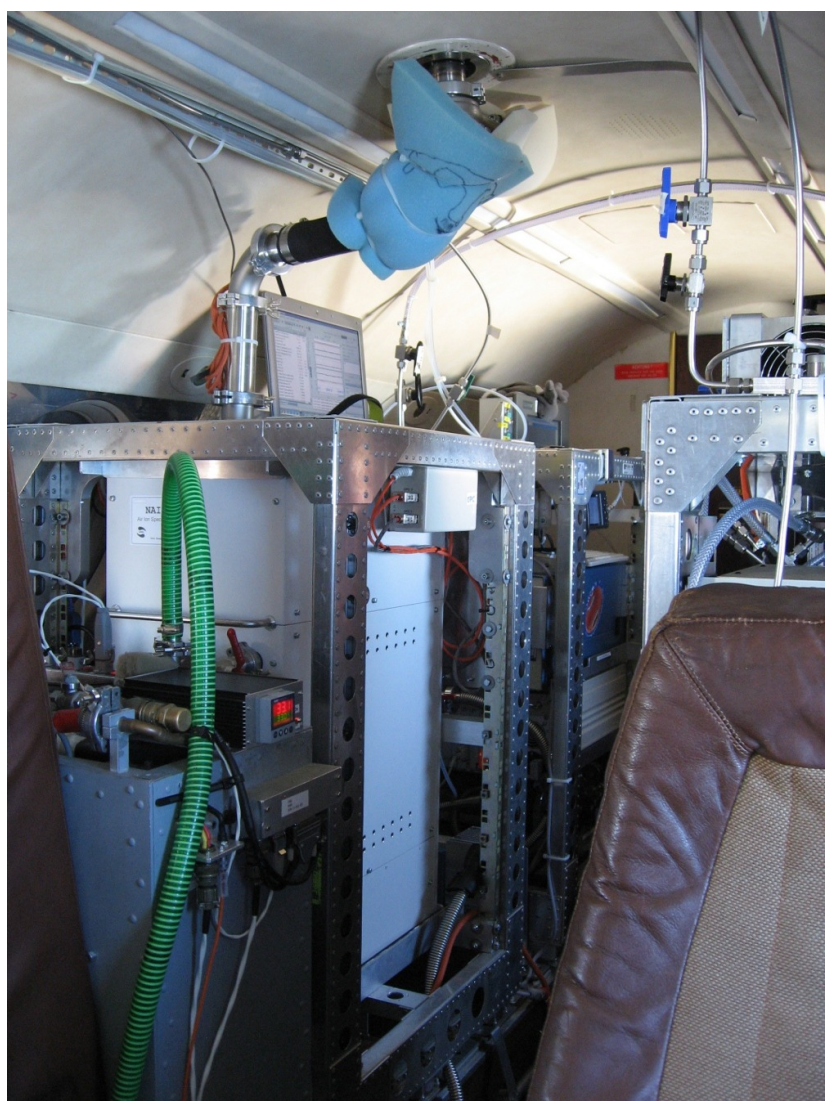

Fig. 2. The NAIS (the box instrument in light grey inside the rack) with connection to the sample air inlet on the top inside the Falcon aircraft.

The instrument operated as expected. The airflows were correctly controlled up to the $8-\mathrm{km}$ altitude. Above that the sheath flow pumps were unable to provide the required flow rate. This caused the measurement range of the instrument to shift towards larger particles. The size shift was corrected in post-processing of the data.

Particle charging did not work ideally at higher altitudes. The decrease of air pressure caused the corona charger currents to increase and become less stable. At the $12-\mathrm{km}$ altitude the average currents were about $130 \%$ of their specified values, which caused some overcharging and consequently the NAIS may have overestimated the particle concentrations by about $10-20 \%$. The elevated charger currents led also to some leakage of charger ions through the post-filters and caused a high concentration of sub- $2 \mathrm{~nm}$ particles to appear in the spectra. This limited the lower size of detectable particles at higher altitudes.

\subsection{Falcon}

The Falcon 20 of DLR is a twin jet aircraft used for atmospheric research with an endurance of about $4 \mathrm{~h}$ and a maximum flight altitude of about $13 \mathrm{~km}$. The scientific payload of the DLR Falcon during the EUCAARI-LONGREX campaign is summarized in Table 1 . It consisted of the DLR WALES lidar system and a combination of in situ instruments for the characterization of aerosol properties (Weinzierl et al., 2009; Minikin et al., 2003) as well as transport tracers (carbon monoxide and ozone). A FSSP-300 aerosol spectrometer probe was used to define the in-cloud sequences during this campaign (using a threshold criterion for the number concentration of particles larger than $3 \mu \mathrm{m}$ ).

The DLR Falcon performed altogether 16 flights in the EUCAARI-LONGREX instrument configuration between 2 May and 24 May 2008. The general flight strategy was to perform flight legs for lidar measurements in the upper troposphere and fly in-between vertical stacked vertical profiles including short (4-5 min) constant level flight legs at several altitudes for vertical soundings with the in-situ instruments between boundary layer and upper troposphere. The flights were performed mostly in coordination with the British FAAM BAe-146 research aircraft. Both aircrafts were operating during the campaign out of the airport of Oberpfaffenhofen in Southern Germany. Flights focused on the region of Central Europe north of the Alps and the Atlantic off the West coast of Ireland (Fig. 3).

\subsection{Condensation particle counter (CPC)}

The aerosol instrumentation payload of the DLR Falcon included a multi-channel condensation particle counter (CPC) system of DLR. It consists of the Condensation Particle Size Analyzer (CPSA), a 4-channel CPC system built by DLR (one channel not operational during this experiment) and two commercial CPCs modified for aircraft use (TSI models 3760A). The CPC channels were set to different minimal detectable particle sizes $(4 \mathrm{~nm}, 10 \mathrm{~nm}$ diameter) through internal control of the butanol saturation. The possible dependence of the particle counting efficiencies of the CPCs on flight altitude (outside pressure) is considered to be small (Hermann and Wiedensohler, 2001). Three CPC channels were combined with a thermodesorber inlet set to $250^{\circ} \mathrm{C}$ to determine the non-volatile particle fraction. CPC number concentrations were corrected for coincidence effects and efficiencies determined in the lab. Corrections for diffusion losses of small particles in the tubing systems have not been made because this requires accurate knowledge on the size distribution in the ultrafine size range. One can estimate, however, that less than $10 \%$ of particles of $10 \mathrm{~nm}$ size and about $35 \%$ of particles of $4 \mathrm{~nm}$ size may get lost in the sampling system due to diffusion losses. The CPC system was sampling through the Falcon near-isokinetic, forward-facing aerosol inlet. 
Table 1. List of DLR Falcon instrumentation during the EUCAARI-LONGREX campaign in May 2008.

\begin{tabular}{|c|c|}
\hline Instrument & Measured parameters \\
\hline WALES High Spectral Resolution Lidar (HRSL) & $\begin{array}{l}\text { extinction profile at } 532 \mathrm{~nm} \text {, backscatter at } 532,925 \& 1064 \mathrm{~nm} \text {, water } \\
\text { vapor at } 532 \mathrm{~nm} \text {, aerosol depolarization }\end{array}$ \\
\hline 5-channel CPC system (unheated/heated) & $\begin{array}{l}\text { total particle number concentration }>10 \mathrm{~nm} \text { (volatile/non-volatile), ul- } \\
\text { trafine particles }\end{array}$ \\
\hline 2-channel Grimm 1.129 OPC (unheated/heated) & $\begin{array}{l}4-10 \mathrm{~nm} \\
\text { particle size distribution } \\
0.25-2 \mu \mathrm{m} \text { (volatile/non-volatile) }\end{array}$ \\
\hline PCASP-100X & particle size distribution $0.15-1 \mu \mathrm{m}$ \\
\hline FSSP-300 & particle size distribution $0.4-20 \mu \mathrm{m}$, cloud elements \\
\hline 3-wavelength-PSAP & absorption coefficient, Angström exponent \\
\hline Neutral cluster and air ion spectrometer (NAIS) & Ultrafine particle/ion size distribution \\
\hline $\mathrm{CO}$ & carbon monoxide mixing ratio \\
\hline Ozone & ozone mixing ratio \\
\hline Falcon "meteorological" data & position, wind, temperature etc., humidity (up to $\sim 8 \mathrm{~km}$ ) \\
\hline Broad-band radiometer & longwave and shortwave radiation flux \\
\hline
\end{tabular}

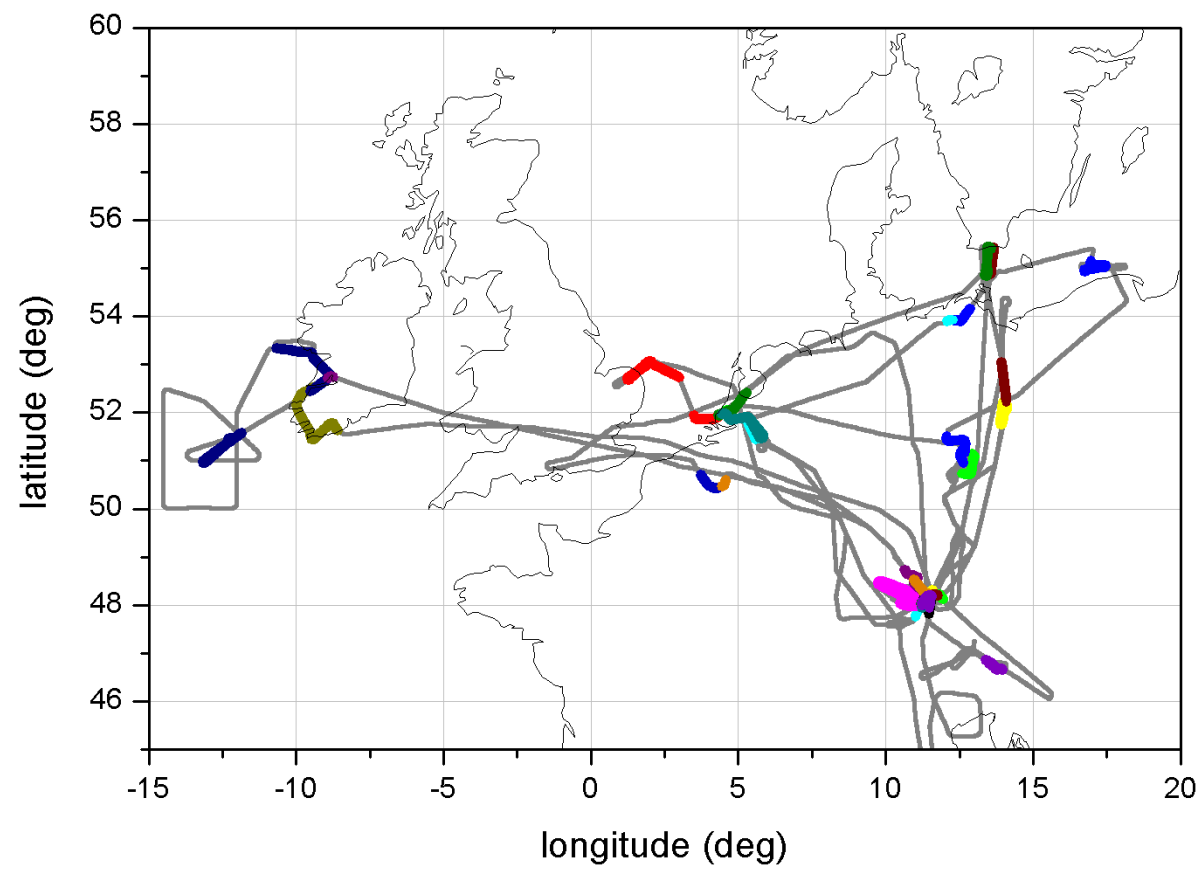

Fig. 3. Map of DLR Falcon flight tracks during the EUCAARI-LONGREX campaign in May 2008. Highlighted are flight sections inside the boundary layer, which indicate the locations where vertical profiles were obtained for in-situ measurements. Different colors show different flights.

\section{Results}

\subsection{General features and data reliability}

In general, the meteorological situation during the first half of the campaign (flights up to 14 May) was characterized by a rather persistent anti-cyclonic system located over central Europe. This situation favored the build-up of pollution in the boundary layer over central Europe, which is the result of the blocking of long-range transport into central Europe and the absence of precipitation, which would cause wet removal of aerosol. Cloudiness was overall very low in this situation. Later during the campaign, weather conditions were more variable and affected by passing of frontal precipitation systems and shallow convection developing during daytime over Central Europe.

The temperature, potential temperature and relative humidity profiles are presented in Fig. 4. 

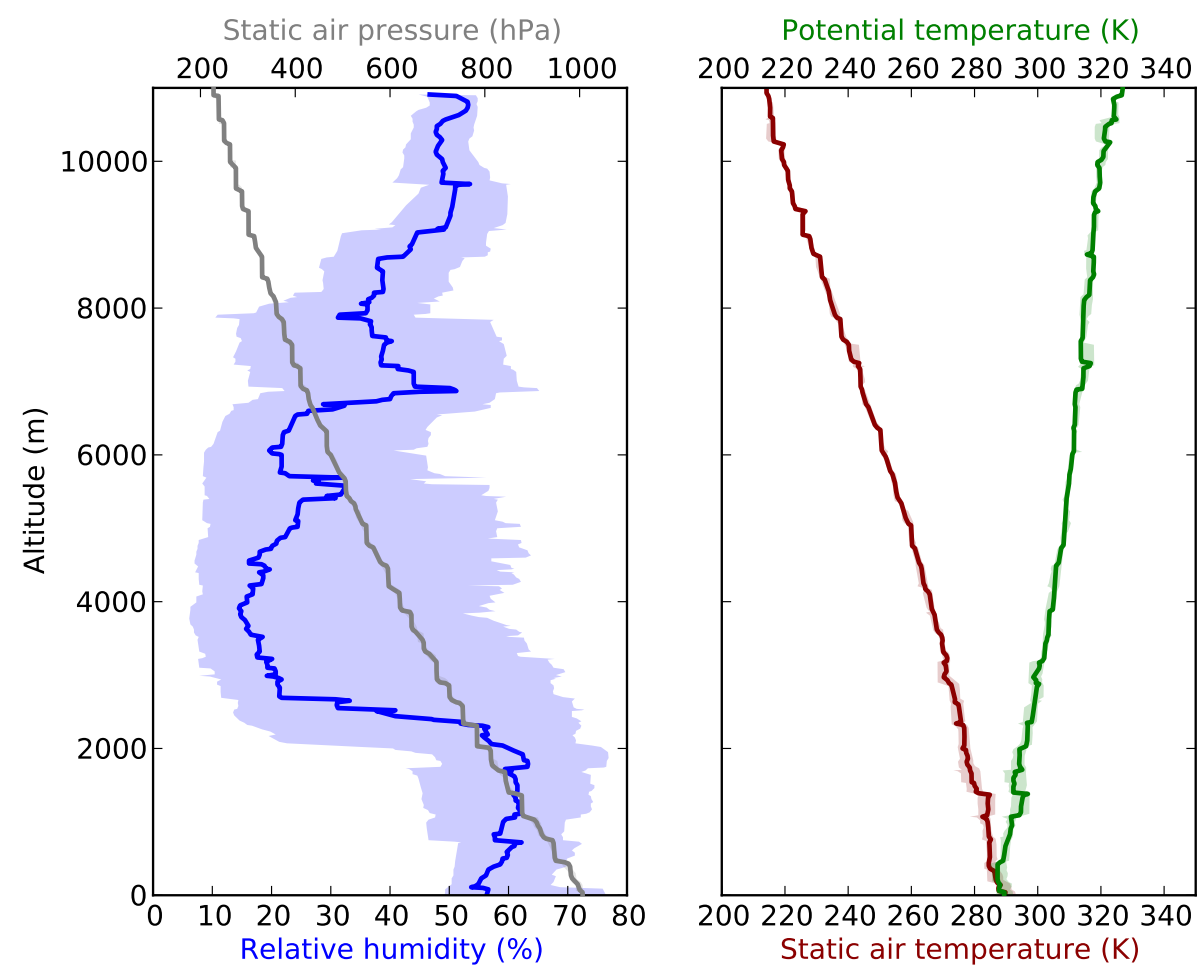

Fig. 4. Temperature, air pressure and humidity medians and quartiles from all flights.

Table 2. Correlation coefficients between concentrations measured using the NAIS and the CPC. Correlations between the logarithms of concentrations are also shown (later one).

\begin{tabular}{llrr}
\hline Fraction limit & NAIS spectrum & Correlation & Log correlation \\
\hline $\mathrm{d}>4 \mathrm{~nm}$ & particles, positive charging & 0.75 & 0.89 \\
$\mathrm{~d}>4 \mathrm{~nm}$ & particles, negative charging & 0.81 & 0.87 \\
$\mathrm{~d}>10 \mathrm{~nm}$ & particles, positive charging & 0.81 & 0.91 \\
$\mathrm{~d}>10 \mathrm{~nm}$ & particles, negative charging & 0.91 & 0.90 \\
$\mathrm{~d}>4 \mathrm{~nm}$ & positive ions & 0.15 & 0.66 \\
$\mathrm{~d}>4 \mathrm{~nm}$ & negative ions & 0.12 & 0.63 \\
$\mathrm{~d}>10 \mathrm{~nm}$ & positive ions & 0.21 & 0.65 \\
$\mathrm{~d}>10 \mathrm{~nm}$ & negative ions & 0.26 & 0.66 \\
\hline
\end{tabular}

Figure 5 shows an example of measured particle number concentrations in one of the flights. We may see that the total particle number concentration varied by roughly two orders of magnitude during the flight, the variability being captured equally well by both the NAIS and the well established Condensation Particle Counter (CPC) system. Both instruments also showed instances of enhanced sub- $10 \mathrm{~nm}$ (and sub- $4 \mathrm{~nm}$ in case of the NAIS) particle concentration, indicating recent atmospheric nucleation in the continental boundary layer (BL) and in the upper troposphere (UT).

We compared the CPC results with matching size fractions from the distributions measured by the NAIS. The Pearson correlation coefficients range between 0.75 and 0.91 when considering results from all altitudes. The Spearman rank ordered correlations are similar. The correlations between the corresponding concentrations and between their logarithms are presented in more detail in Table 2. Scatterplots comparing the results from the CPC and the NAIS are presented in Fig. 6.

Comparisons between the CPC and matching ion fractions from the NAIS show a significantly lower correlation. This may indicate their somewhat independent origin. Increased contribution of measurement noise due to low ion signal can also be a factor.

Average concentrations shown by the CPC-s are 2-3 times lower than measured by NAIS for particles larger than $4 \mathrm{~nm}$ 
Table 3. Average concentrations from the CPC and the NAIS in different size fractions, operating modes and altitude ranges (\#/ $\left.\mathrm{cm}^{3}\right)$

\begin{tabular}{lrrr}
\hline & all altitudes & below 3 km & above $3 \mathrm{~km}$ \\
\hline CPC & & & \\
Larger than 4 nm & 2070 & 5426 & 768 \\
Larger than 10 nm & 1755 & 4670 & 624 \\
\hline NAIS particles & & & \\
4-42 nm, positive charging & 5019 & 14173 & 1494 \\
10-42 nm, positive charging & 3075 & 8953 & 811 \\
$4-42$ nm, negative charging & 5671 & 15741 & 1793 \\
$10-42$ nm, negative charging & 3515 & 10078 & 988 \\
\hline NAIS ions & & & \\
$4-42$ nm, positive ions & 699 & 2059 & 168 \\
$10-42$ nm, positive ions & 307 & 883 & 81 \\
$4-42$ nm, negative ions & 826 & 2361 & 226 \\
$10-42$ nm, negative ions & 279 & 757 & 92 \\
\hline
\end{tabular}
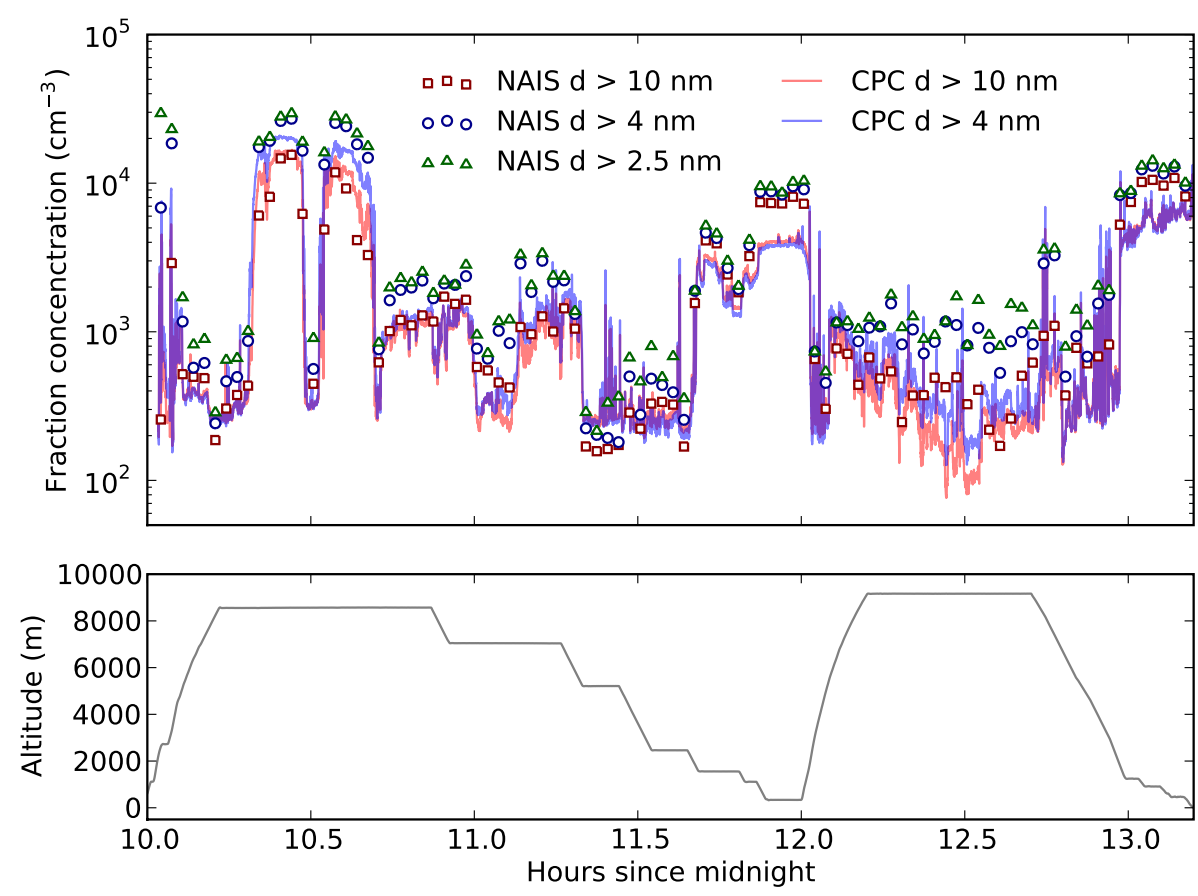

Fig. 5. Time-altitude profiles particle number concentrations measured by NAIS and the CPC system between 10:00 and 13:15 on 21 May. From the CPC data, number concentrations of particles $>4$ and $>10 \mathrm{~nm}$ in diameter are obtained. The difference between these two CPC curves is indicative of atmospheric nucleation. The NAIS data shows also the number concentration of particles $>2.5 \mathrm{~nm}$ in diameter, making it possible to identify more recent nucleation events than with the CPC system.

and less than 2 times lower for particles larger than $10 \mathrm{~nm}$. The NAIS may have slightly overestimated the concentrations due to overcharging (see Sect. "Operation on-board the aircraft"). The CPC may have underestimated the concentrations due to higher inlet losses. The average concentrations are presented in Table 3.
These comparisons give confidence on the ability of the NAIS to measure both particles and clusters during the flights presented here. 

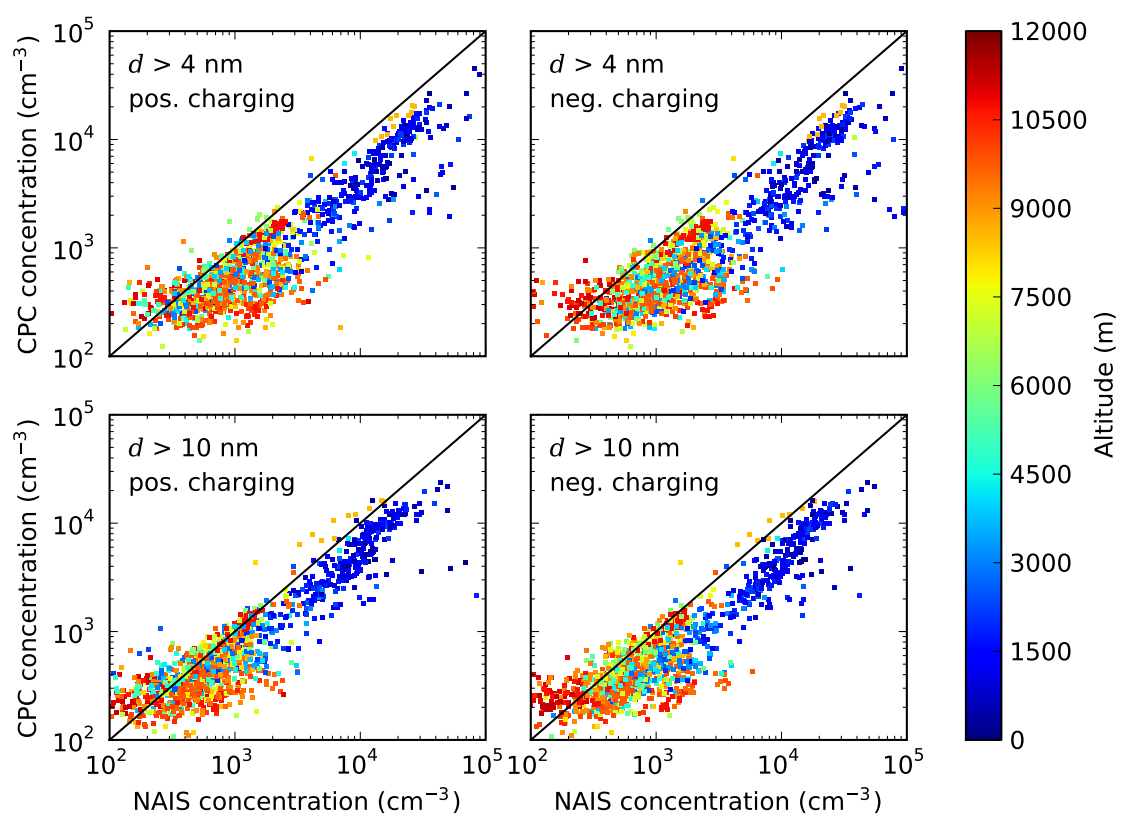

Fig. 6. Comparison of concentrations measured using NAIS and CPC at different size ranges.

\subsection{Cluster size distributions and implications for nu- cleation}

A composite of all cluster size distributions from different flight altitudes measured with the NAIS is shown in Fig. 7. Charged particles displayed a narrow concentration band, or mode, centered close to $1 \mathrm{~nm}$ throughout the tropospheric column. A similar cluster ion pool has been observed in practically all ground-based measurements made so far (Kulmala et al., 2007; Vartiainen et al., 2007; Suni et al., 2008; Venzac et al., 2007), reflecting the fact that small ion clusters are being continually formed in the atmosphere. Another mode of charged particles can be distinguished at sizes above roughly $20 \mathrm{~nm}$. This mode results from the attachment of cluster ions with pre-existing larger particles. The mode was strongest below $2 \mathrm{~km}$, which is expected due to the larger concentrations of Aitken mode particles in continental boundary layers as compared with the free troposphere (Raes et al., 2000). Interestingly, total concentrations of clusters smaller than $3 \mathrm{~nm}$ in diameter were much larger than those of similar-sized charged clusters at all altitude levels. This means that there was a continuous pool of sub- $3 \mathrm{~nm}$ neutral clusters throughout the troposphere. Such a neutral cluster pool, while recently identified in a continental boundary layer (Kulmala et al., 2007), has never before been observed in the free troposphere.

In order to get further insight into new particle formation in the FT, we determined the vertical concentration profiles of total and charged clusters/particles measured by the NAIS at two size ranges (Fig. 8a and c), along with the respective concentration ratios (Fig. 8b and d). In the size range of $2.5-3 \mathrm{~nm}$, median concentrations of positively and negatively charged clusters varied little with altitude and were similar to each other. Concentrations of neutral clusters exceeded those of charged clusters by at least a factor of 50 on average, and at several altitude levels by a factor larger than 150 . In the size range 4-10 nm, both charged and total particles showed a maximum below $2 \mathrm{~km}$ and a minimum between about 4 and $6 \mathrm{~km}$. This is consistent with observations of the vertical distribution of particles in roughly the same size range using CPCs during EUCAARI and also during other airborne studies at mid-latitudes (not shown). Total $4-10 \mathrm{~nm}$ particle concentrations exceeded those of charged ones by a factor of 10-100 depending on the altitude. Taken together, these observations point toward a continuous aerosol particle formation by nucleation processes throughout the troposphere.

In charge equilibrium and within the boundary layer, the ratio between total and charged particle was calculated to be around 90 for the size range $2.5-3 \mathrm{~nm}$ and about 30 for the size range $4-10 \mathrm{~nm}$. This means that below about $2 \mathrm{~km}$, clusters and sub- $10 \mathrm{~nm}$ particles carried on average less charge than would be expected based on charge equilibrium. This indicates strongly that these particles were formed via neutral rather than ion-induced pathways (Iida et al., 2006; Laakso et al., 2007; Kerminen et al., 2007). The dominance of neutral over ion-induced nucleation is consistent with recent 


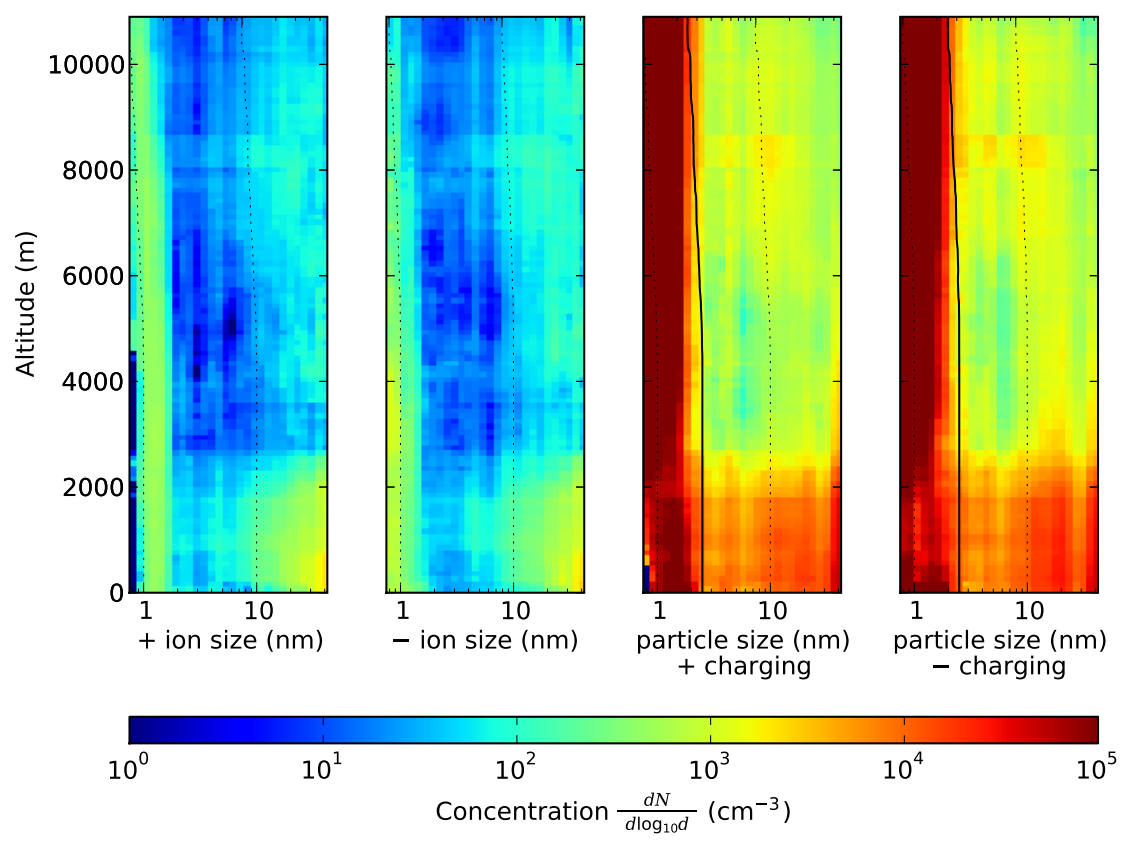

Fig. 7. Median concentrations of positively and negatively charged clusters and particles (two panels on the left) as a function of altitude and particle size (mobility equivalent diameter) measured using the NAIS from all the flights. Panels on the right display the corresponding total (neutral + charged) cluster/particle concentrations, as recorded by the two (positive and negative) polarity channels of the NAIS. Ions produced by the NAIS corona charger perturb the measurement of the smallest clusters on the two panels on the right. A detailed analysis shows that this perturbation affects only the size range $<2 \mathrm{~nm}$ in the boundary layer, reaching the size of $2.5 \mathrm{~nm}$ at about the $7-8 \mathrm{~km}$ altitude. The limit of $2.5 \mathrm{~nm}$ has been marked with a solid black line in these panels.

findings from ground-level sites (Kulmala et al., 2007; Iida et al., 2006; Laakso et al., 2007; Manninen et al., 2009). Theoretically, the most favorable tropospheric region for ioninduced nucleation is the upper FT (Yu et al., 2008; Kazil et al., 2008). A transition from dominant neutral nucleation below $2 \mathrm{~km}$ to ion-induced nucleation in the upper free troposphere should be seen as a clear decrease in the concentration ratio between total and charged clusters with an increasing height. Our data show no signs of such a decrease toward the upper FT (Fig. 8b and d).

The altitude dependence of the concentration of $0.75-2 \mathrm{~nm}$ sized ions is presented in Fig. 9. The measured concentrations are affected by the close proximity of the lower particle size limit of the instrument. Above $4 \mathrm{~km}$ the instrument starts to lose part of the negative cluster ions due to the shift of the measurement size range.

Histograms of particle to ion concentration ratios at different altitudes for $4.0-10 \mathrm{~nm}$ and $2.5-3.0 \mathrm{~nm}$ size ranges are presented in Figs. 10 and 11 respectively. It can be seen that the distribution of the ratios remains nearly constant regardless of altitude.

\subsection{Influence of clouds}

In many earlier studies, free-tropospheric aerosol particle formation has been associated with the presence of clouds, especially with the outflow regions of deep convective clouds (Ekman et al., 2008; Twohy et al., 2002; Weigelt et al., 2009; Kulmala et al., 2006). During our flights, clouds occupied on average between about 5 and $15 \%$ of the FT, with no apparent height dependence (Fig. 12).

We grouped our data into "in-cloud" and "out-of-cloud" periods to look for the potential influence of clouds. The presence of cloud around the aircraft was decided based on the concentration of 3-20 $\mu \mathrm{m}$ particles, which was measured by an on-board FSSP-300.

Comparison of these two data sets was hampered by the scarcity of our "in-cloud" measurements. In general terms, however, we may state that concentrations of charged clusters/particles were one to three orders of magnitude higher during "in-cloud" periods than during "out-of-cloud" periods, especially at lower altitudes $(<4 \mathrm{~km})$. For total clusters/particles, no consistent differences between the two data sets could be identified.

The enhanced presence of charged sub- $10 \mathrm{~nm}$ particles inside clouds might be explained by the production of ions of 

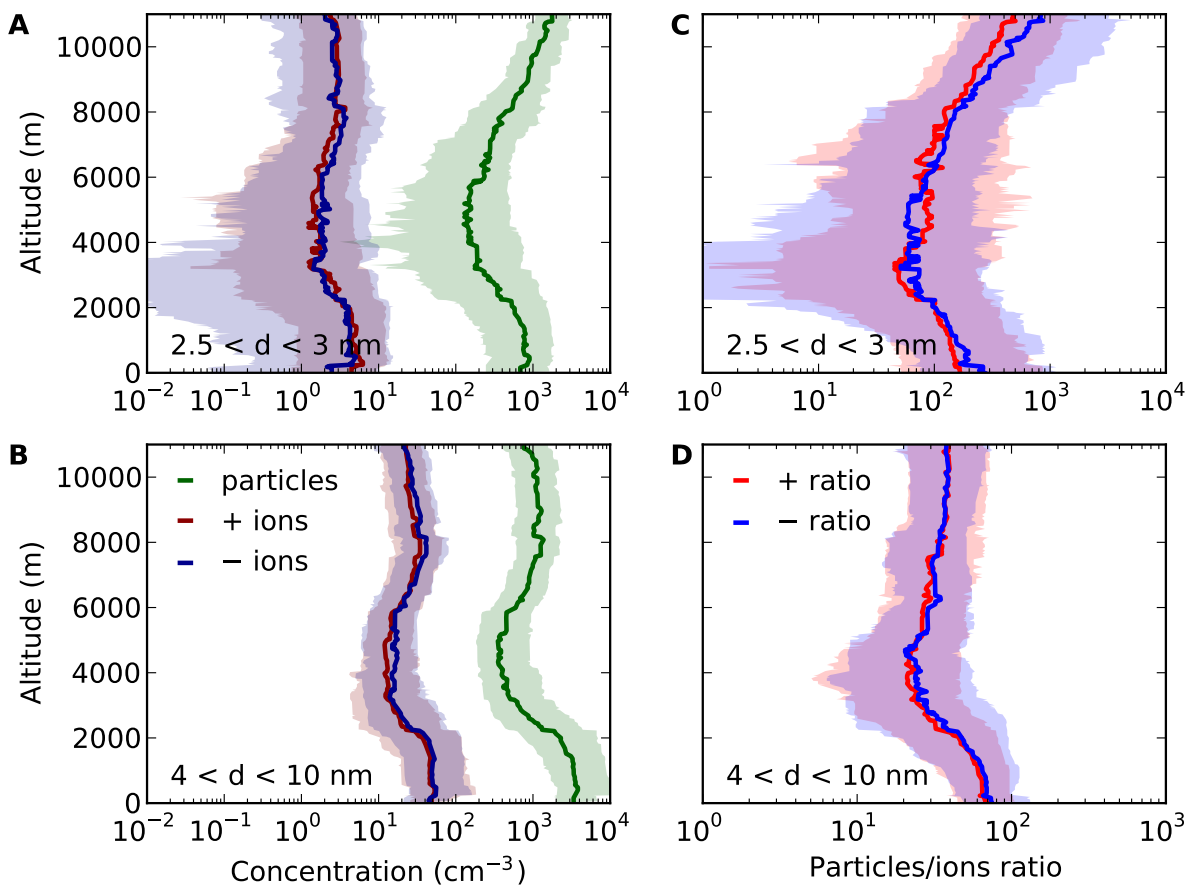

Fig. 8. Median concentration profiles total (green) and charged (dark red and blue) clusters and particles in diameter size ranges 2.5-3 nm (a) and 4-10 nm (b), as well as the corresponding concentration ratios between total and charged cluster/particles (c and d), derived from measurements from all flights of the EUCAARI LONGREX campaign in May 2008. Solid line shows the median over all measurement flights, while the shading represents 25 and $75 \%$ percentiles of the data.

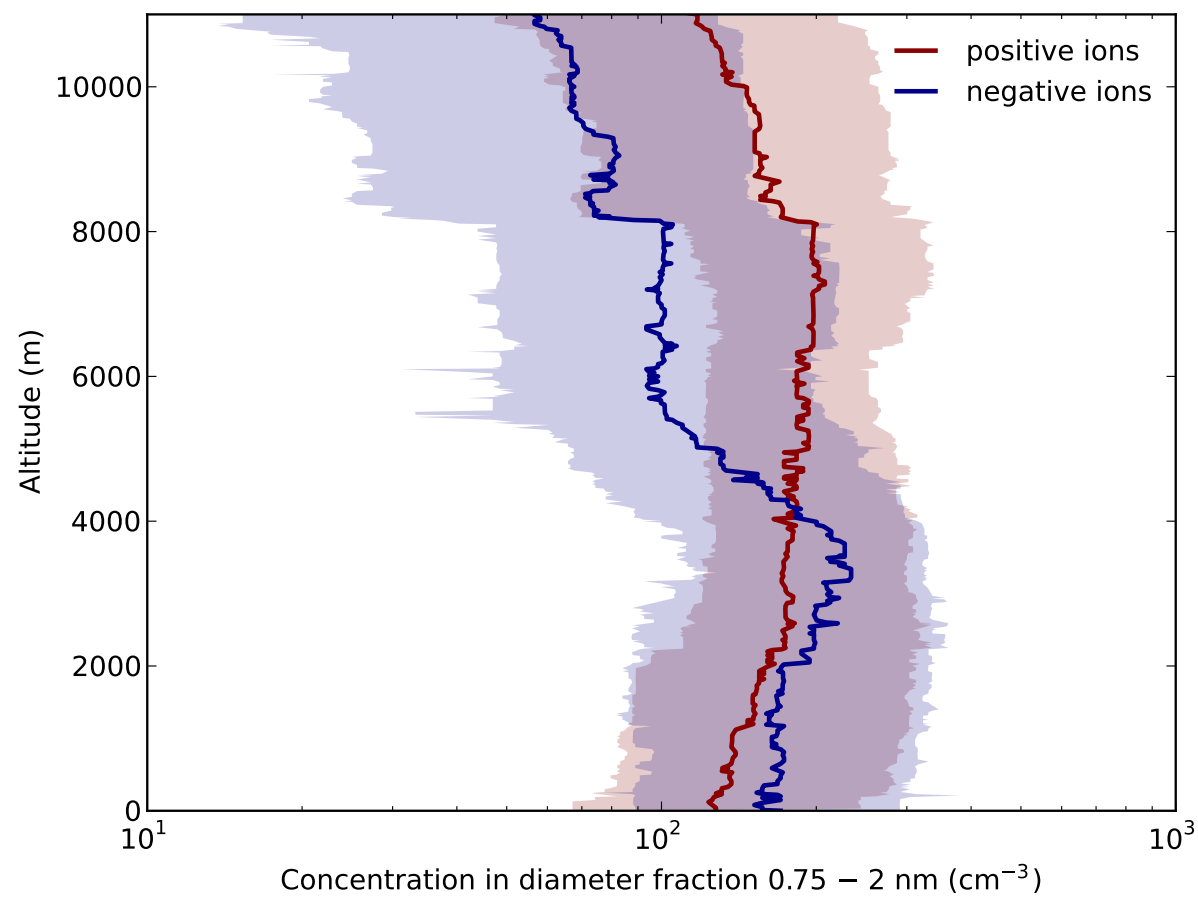

Fig. 9. Positive (red) and negative (blue) small ion concentration as a function of altitude - medians and 25 and $75 \%$ quantiles are presented. Part of the negative ions are not detected above $4 \mathrm{~km}$ due to the shift of the measurement range of the instrument. 
Particles/ions ratio histograms for diameter size range 4 - $10 \mathrm{~nm}$
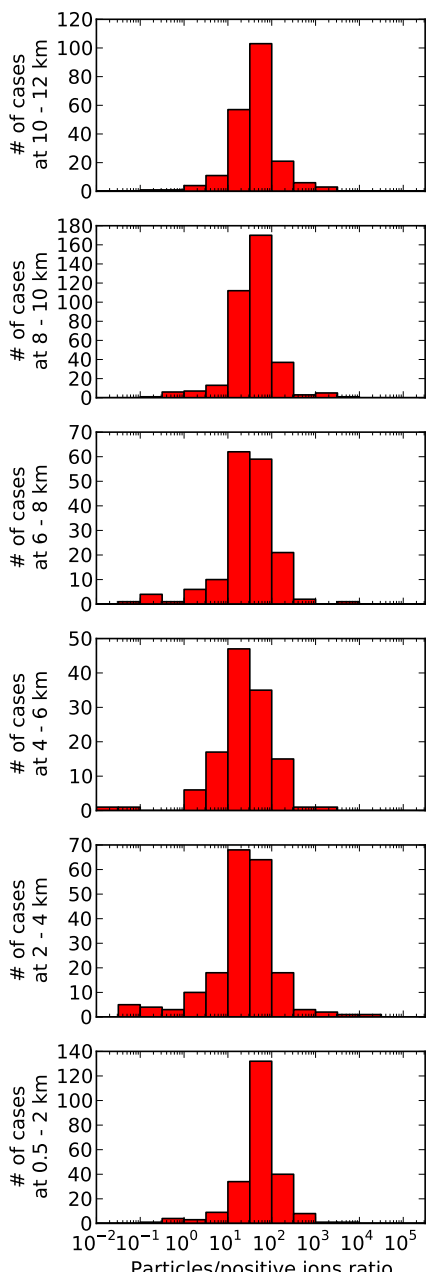

Particles/positive ions ratio
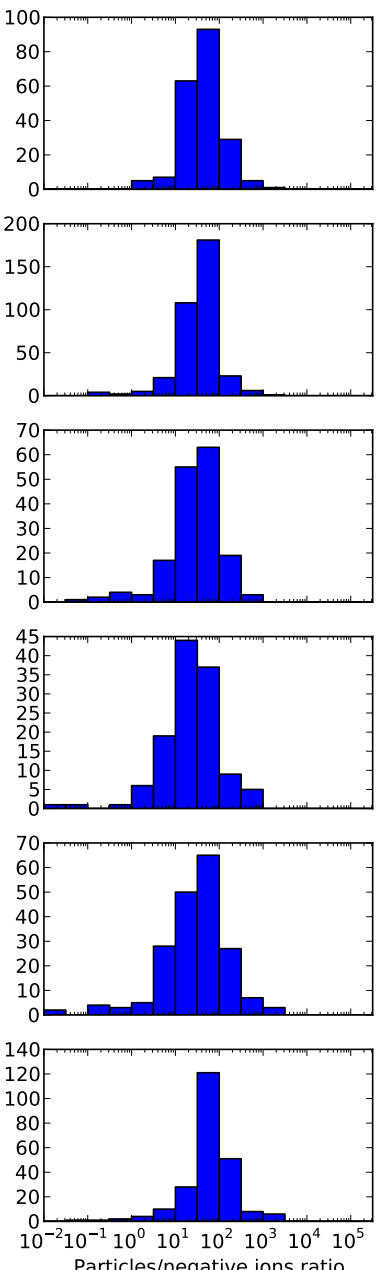

Fig. 10. Histograms of concentration ratios of particles to positive (red) and negative (blue) ions in the diameter size range $4-10 \mathrm{~nm}$ at different altitude ranges.

a few $\mathrm{nm}$ in diameter by balloelectric effects during rain, as seen in surface observations (Tammet et al., 2009), or it could be a sampling artifact. The histograms of number concentrations in the size range $2.5-3 \mathrm{~nm}$ separately for "in-cloud" and "out-of-cloud" cases are presented in Fig. 13.

In order to find out whether clouds could influence the overall budget or profiles of sub-10 $\mathrm{nm}$ particles during our measurements, we compared the vertical profiles of total and charged $2.5-3 \mathrm{~nm}$ clusters and $4-10 \mathrm{~nm}$ particles during the "out-of-cloud" periods with the corresponding profiles representing the whole data set shown by Fig. 8 . The profiles were very similar, indicating a minor overall effect by clouds.
Particles/ions ratio histograms for diameter size range $2.5-3 \mathrm{~nm}$
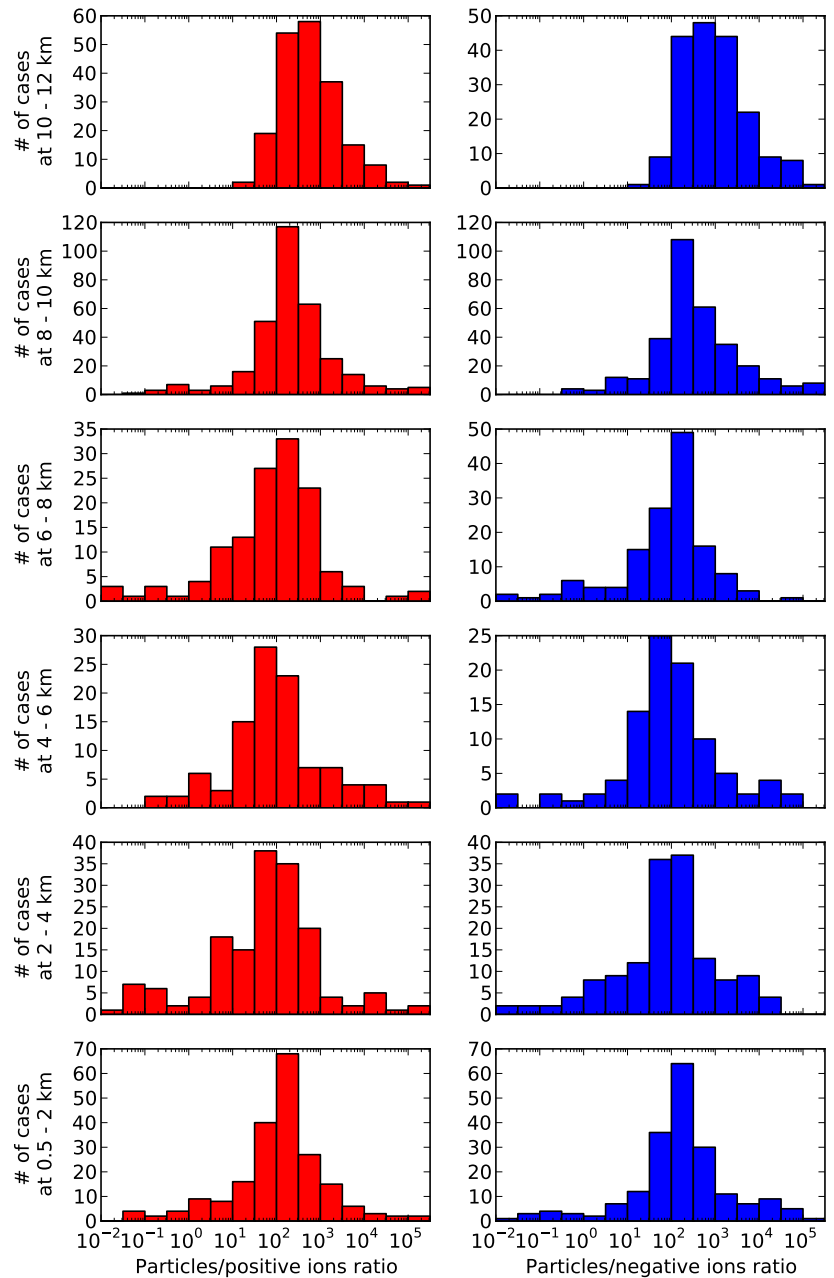

Fig. 11. Histograms of concentration ratios of particles to positive (red) and negative (blue) ions in the diameter size range $2.5-3 \mathrm{~nm}$ at different altitude ranges.

\section{Conclusions}

The NAIS instrument, with a new design for airborne measurement purposes, was tested and applied for the first time in an aircraft. We found that the instrument measures reliably the concentrations and size distributions of neutral and charged particles down to mobility diameters of 2 $2.5 \mathrm{~nm}$ throughout the tropospheric column. Most importantly, detection of sub-3 nm neutral clusters with the instrument makes it possible to investigate free-troposphere nucleation in much more detail than what has been possible until now.

Airborne measurements made so far have shown that nucleation mode particles $(3-20 \mathrm{~nm})$ tend to occur mainly in two altitude regions in the troposphere: in the well-mixed continental boundary layer and in the upper troposphere 

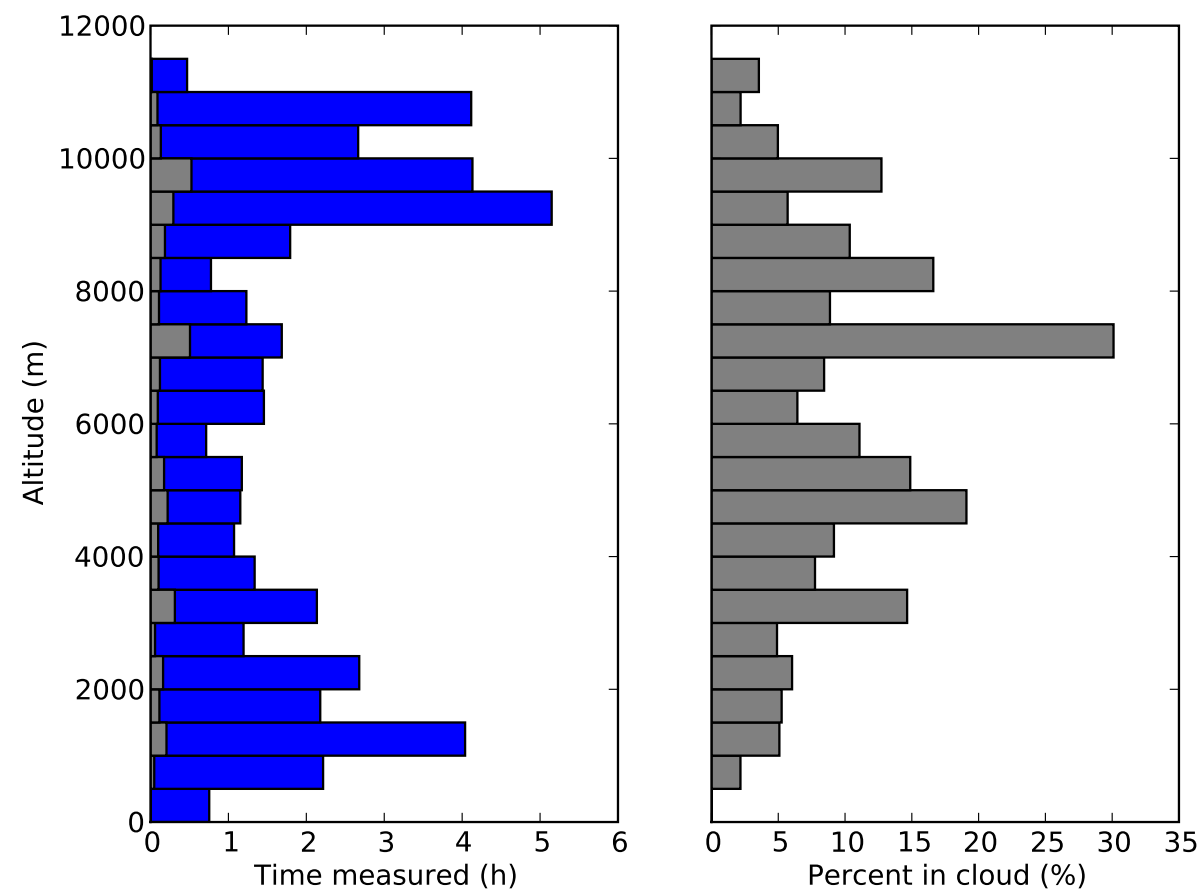

Fig. 12. Amount of time the aircraft spent at different altitudes in total (blue bars) and in clouds (gray bars).
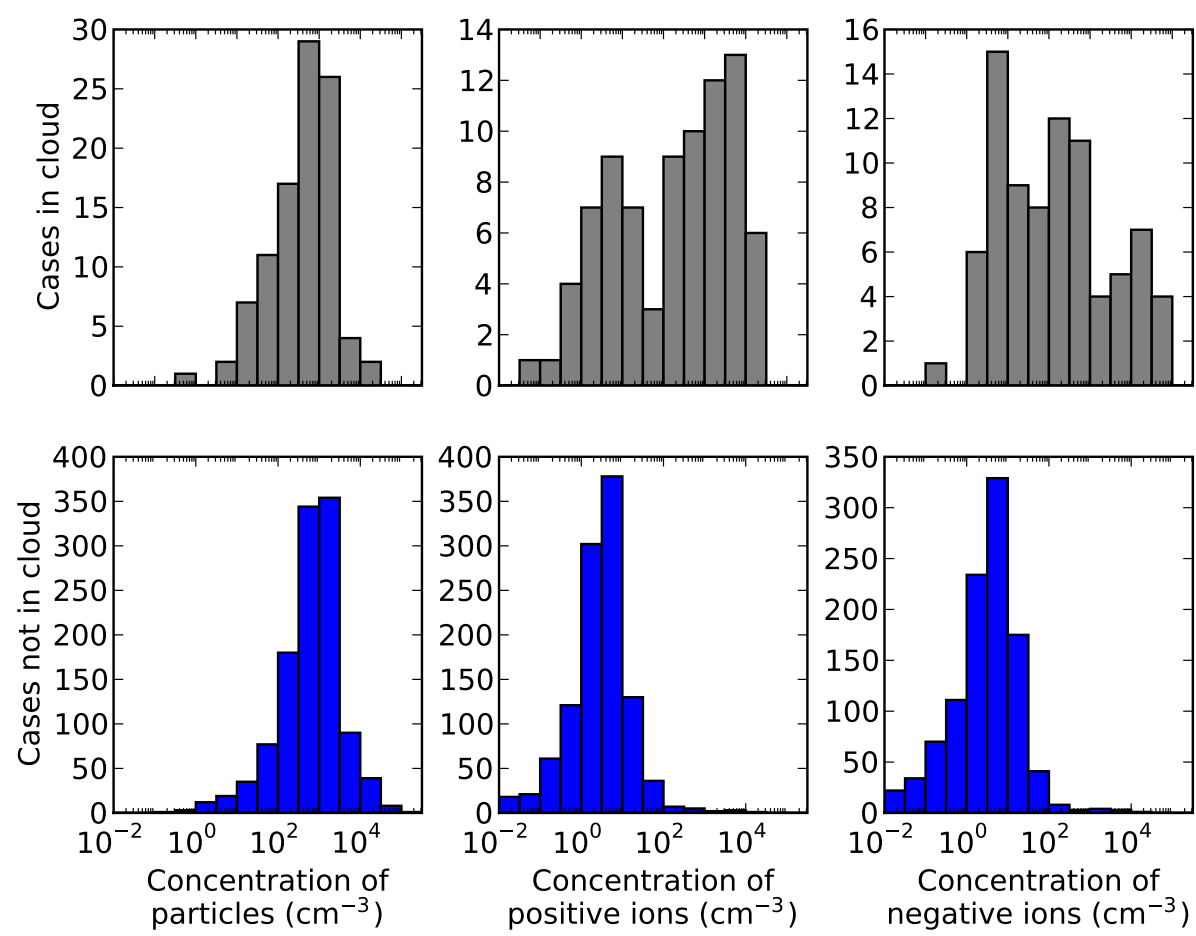

Fig. 13. Histograms of 2.5-3 nm diameter particle concentrations. Gray bars show only "in-cloud" cases, blue bars show only "out-of-cloud" cases. 
(UT). This, together with theoretical studies and surface observations, have led people to think i) that atmospheric nucleation occurs preferably in the continental boundary layer and the UT, with little particle production taking place in between, ii) that the nucleation mechanism is different between these two layers, and iii) that nucleation in the UT is associated with clouds and/or ion-induced pathways. The measurements reported here demonstrate that this view may not be entirely correct. The abundant presence of both neutral and charged sub- $3 \mathrm{~nm}$ clusters observed at all altitude levels is indicative of frequent nucleation taking place throughout the tropospheric column. Further growth of nucleated particles seems to be hindered in mid troposphere $(4-6 \mathrm{~km})$. Consistent with earlier studies, we found that nucleation was dominated by neutral pathways in the lower troposphere. However, no sign of an enhanced role of ion-induced nucleation toward the tropopause region was observed, contrary to theoretical arguments. Clouds seemed to produce charged clusters, but the probable formation mechanism was rain rather than homogeneous nucleation. The overall budget of sub$10 \mathrm{~nm}$ particles was not affected significantly by the presence of clouds during our measurements.

This work demonstrates that we may need to re-evaluate the free-troposphere source of atmospheric aerosol particles and related nucleation mechanisms e.g. by making observations in convective outflows and other FT regions. Since the climatic and other effects of nucleated clusters depend eventually on how big fraction of them survives to sizes of $50-100 \mathrm{~nm}$ in diameter, we should complement the existing global model studies on this subject (Spracklen et al., 2008; Pierce and Adams, 2009; Wang and Penner, 2009; Makkonen et al., 2009) with the new information obtained here. More measurements are required from different locations around the world to confirm our findings.

Acknowledgements. Financial support by European Commission 6th Framework programme project EUCAARI, contract no 036833-2 (EUCAARI), The Academy of Finland, and Estonian Research Council (project SF0180043s08) is gratefully acknowledged.

Edited by: E. Swietlicki

\section{References}

Arnold, F.: Atmospheric aerosol and cloud condensation nuclei formation: A possible influence of cosmic rays?, Space Sci. Rev., 125, 169-186, 2006.

Asmi, E., Sipilä, M., Manninen, H. E., Vanhanen, J., Lehtipalo, K., Gagné, S., Neitola, K., Mirme, A., Mirme, S., Tamm, E., Uin, J., Komsaare, K., Attoui, M., and Kulmala, M.: Results of the first air ion spectrometer calibration and intercomparison workshop, Atmos. Chem. Phys., 9, 141-154, 2009, http://www.atmos-chem-phys.net/9/141/2009/.

Baker, M. and Peter, T.: Small-scale cloud processes and climate, Nature, 451, 299-300, 2008.
Benson, D. R., Young, L.-H., Lee, S.-H., Campos, T. L., Rogers, D. C., and Jensen, J.: The effects of airmass history on new particle formation in the free troposphere: case studies, Atmos. Chem. Phys., 8, 3015-3024, 2008, http://www.atmos-chem-phys.net/8/3015/2008/.

Brock, C., Hamill, P., Wilson, J., Jonsson, H., and Chan, K.: Particle formation in the upper tropical troposphere: A source of nuclei for the stratospheric aerosol, Science, 270, 1650-1653, 1995.

Clarke, A.: Atmospheric nuclei in the Pacific midtroposphere: Their nature, concentration, and evolution, J. Geophys. Res., 98, 20633-20647, 1993.

de Reus, M., Ström, J., Curtius, J., Pirjola, L., Vignati, E., Arnold, F., Hansson, H., Kulmala, M., Lelieveld, J., and Raes, F.: Aerosol production and growth in the upper free troposphere, J. Geophys. Res., 105, 24751-24762, 2000.

Ekman, A., Krejci, R., Engström, A., Ström, J., de Reus, M., Williams, J., and Andreae, M.: Do organics contribute to small particle formation in the Amazonian upper troposphere?, Geophys. Res. Lett., 35, L17810, doi:10.1029/2008GL034970, 2008.

Fuchs, N. A.: The Mechanics of Aerosols, Pergamon Press, Oxford, 1964.

Fuchs, N. A. and Sutugin, A. G.: Highly dispersed aerosols, vol. H of In Topics in Current Aerosol Research, Pergamon Press, New York, USA, 1971.

Hermann, M. and Wiedensohler, A.: Counting efficiency of condensation particle counters at low-pressures with illustrative data from the upper troposphere, Journal of Aerosol Science, 32, 975991, 2001.

Iida, K., Stolzenburg, M., McMurry, P., Dunn, M., Smith, J., Eisele, F., and Keady, P.: Contribution of ion-induced nucleation to new particle formation: Methodology and its application to atmospheric observations in Boulder, Colorado, J. Geophys. Res., 111, D23201, doi:10.1029/2006JD007167, 2006.

Kanawade, V. and Tripathi, S.: Evidence for the role of ioninduced particle formation during an atmospheric nucleation event observed in Tropospheric Ozone Production about the Spring Equinox (TOPSE), J. Geophys. Res., 111, D02209, doi: 10.1029/2005JD006366, 2006.

Kazil, J. and Lovejoy, E.: Tropospheric ionization and aerosol production: A model study, J. Geophys. Res., 109, D19206, doi: 10.1029/2004JD004852, 2004.

Kazil, J., Harrison, R., and Lovejoy, E.: Tropospheric new particle formation and the role of ions, Space Sci. Rev., 137, 241-255, 2008.

Kerminen, V., Anttila, T., Petäjä, T., Laakso, L., Gagné, S., Lehtinen, K., and Kulmala, M.: Charging state of the atmospheric nucleation mode: Implications for separating neutral and ioninduced nucleation, J. Geophys. Res., 112, D21205, doi:10.1029/ 2007JD008649, 2007.

Koren, I., Martins, J., Remer, L., and Afargan, H.: Smoke invigoration versus inhibition of clouds over the Amazon, Science, 321, 946-949, 2008.

Korhonen, H., Carslaw, K., Spracklen, D., Mann, G., and Woodhouse, M.: Influence of oceanic dimethyl sulfide emissions on cloud condensation nuclei concentrations and seasonality over the remote Southern Hemisphere oceans: A global model study, J. Geophys. Res., 113, D15204, doi:10.1029/2007JD009718, 2008.

Kulmala, M. and Kerminen, V.: On the formation and growth of 
atmospheric nanoparticles, Atmos. Res., 90, 132-150, 2008.

Kulmala, M., Vehkamäki, H., Petäjä, T., Dal Maso, M., Lauri, A., Kerminen, V., Birmili, W., and McMurry, P.: Formation and growth rates of ultrafine atmospheric particles: a review of observations, J. Aerosol Sci., 35, 143-176, 2004.

Kulmala, M., Reissell, A., Sipilä, M., Bonn, B., Ruuskanen, T., Lehtinen, K., Kerminen, V., and Ström, J.: Deep convective clouds as aerosol production engines: Role of insoluble organics, J. Geophys. Res, 111, D17202, doi:10.1029/2005JD006963, 2006.

Kulmala, M., Riipinen, I., Sipilä, M., Manninen, H. E., Petäjä, T., Junninen, H., Maso, M. D., Mordas, G., Mirme, A., Vana, M., Hirsikko, A., Laakso, L., Harrison, R. M., Hanson, I., Leung, C., Lehtinen, K. E., and Kerminen, V.-M.: Towards direct measurement of atmospheric nucleation, Science, 318, 89-92, 2007.

Kulmala, M., Asmi, A., Lappalainen, H. K., Carslaw, K. S., Pöschl, U., Baltensperger, U., Hov, Ø., Brenquier, J.-L., Pandis, S. N., Facchini, M. C., Hansson, H.-C., Wiedensohler, A., and O'Dowd, C. D.: Introduction: European Integrated Project on Aerosol Cloud Climate and Air Quality interactions (EUCAARI) - integrating aerosol research from nano to global scales, Atmos. Chem. Phys., 9, 2825-2841, 2009, http://www.atmos-chem-phys.net/9/2825/2009/.

Laakso, L., Gagne, S., Petaja, T., Hirsikko, A., Aalto, P., Kulmala, M., and Kerminen, V.: Detecting charging state of ultra-fine particles: instrumental development and ambient measurements, Atmos. Chem. Phys., 7, 1333-1345, 2007,

http://www.atmos-chem-phys.net/7/1333/

2007/http://www.atmos-chem-phys.net/7/1333/2007/.

Laaksonen, A., Pirjola, L., Kulmala, M., Wohlfrom, K.-H., Arnold, F., and Raes, F.: Upper tropospheric SO2 conversion into sulphuric acid aerosols and cloud condensation nuclei, J. Geophys. Res., 105, 1459-1468, 2000.

Lohman, U. and Feichter, J.: Global indirect aerosol effects: a review, Atmos. Chem. Phys., 5, 715-737, 2005, http://www.atmos-chem-phys.net/5/715/2005/.

Makkonen, R., Asmi, A., Korhonen, H., Kokkola, H., Järvenoja, S., Räisänen, P., Lehtinen, K. E. J., Laaksonen, A., Kerminen, V.M., Järvinen, H., Lohmann, U., Bennartz, R., Feichter, J., and Kulmala, M.: Sensitivity of aerosol concentrations and cloud properties to nucleation and secondary organic distribution in ECHAM5-HAM global circulation model, Atmos. Chem. Phys., 9, 1747-1766, 2009,

http://www.atmos-chem-phys.net/9/1747/2009/.

Manninen, H. E., Nieminen, T., Riipinen, I., Yli-Juuti, T., Gagné, S., Asmi, E., Aalto, P. P., Petäjä, T., Kerminen, V.-M., and Kulmala, M.: Charged and total particle formation and growth rates during EUCAARI 2007 campaign in Hyytiälä, Atmos. Chem. Phys., 9, 4077-4089, 2009,

http://www.atmos-chem-phys.net/9/4077/2009/.

Minikin, A., Petzold, A., Strom, J., Krejci, R., Seifert, M., van Velthoven, P., Schlager, H., and Schumann, U.: Aircraft observations of the upper tropospheric fine particle aerosol in the Northern and Southern Hemispheres at midlatitudes, Geophys. Res. Lett., 30, 1503, doi:10.1029/2002GL016458, 2003.

Mirme, A., Tamm, E., Mordas, G., Vana, M., Uin, J., Mirme, S., Bernotas, T., Laakso, L., Hirsikko, A., and Kulmala, M.: A wide range multi-channel Air Ion Spectrometer, Boreal Env. Res., 12, 247-264, 2007.
O’Dowd, C. D., Yoon, Y. J., Junkerman, W., Aalto, P., Kulmala, M., Lihavainen, H., and Viisanen, Y.: Airborne measurements of nucleation mode particles I: coastal nucleation and growth rates, Atmos. Chem. Phys., 7, 1491-1501, 2007,

http://www.atmos-chem-phys.net/7/1491/2007/.

O’Dowd, C. D., Yoon, Y. J., Junkermann, W., Aalto, P., Kulmala, M., Lihavainen, H., and Viisanen, Y.: Airborne measurements of nucleation mode particles II: boreal forest nucleation events, Atmos. Chem. Phys., 9, 937-944, 2009, http://www.atmos-chem-phys.net/9/937/2009/.

Pierce, J. and Adams, P.: Uncertainty in global CCN concentrations from uncertain aerosol nucleation and primary emission rates, Atmos. Chem. Phys., 9, 1339-1356, 2009, http://www.atmos-chem-phys.net/9/1339/2009/.

Raes, F.: Entrainment of free tropospheric aerosols as a regulating mechanism for cloud condensation nuclei in the remote marine boundary layer, J. Geophys. Res., 100, 2893-2903, 1995.

Raes, F., Dingenen, R., Vignati, E., Wilson, J., Putaud, J., Seinfeld, J., and Adams, P.: Formation and cycling of aerosols in the global troposphere, Atmos. Environ., 34, 4215-4240, 2000.

Rosenfeld, D., Lohmann, U., Raga, G., O’Dowd, C., Kulmala, M., Fuzzi, S., Reissell, A., and Andreae, M.: Flood or drought: How do aerosols affect precipitation?, Science, 321, 1309-1313, doi: 10.1126/science.1160606, 2008.

Sipilä, M., Lehtipalo, K., Kulmala, M., Petäjä, T., Junninen, H., Aalto, P. P., Manninen, H. E., Kyrö, E.-M., Asmi, E., Riipinen, I., Curtius, J., Kürten, A., Borrmann, S., and O'Dowd, C. D. Applicability of condensation particle counters to measure atmospheric clusters, Atmos. Chem. Phys., 8, 4049-4060, 2008, http://www.atmos-chem-phys.net/8/4049/2008/.

Spracklen, D., Carslaw, K., Kulmala, M., Kerminen, V., Sihto, S., Riipinen, I., Merikanto, J., Mann, G., Chipperfield, M., Wiedensohler, A., et al.: Contribution of particle formation to global cloud condensation nuclei concentrations, Geophys. Res. Lett., 35, L06808, doi:10.1029/2007GL033038, 2008.

Suni, T., Kulmala, M., Hirsikko, A., Bergman, T., Laakso, L., Aalto, P. P., Leuning, R., Cleugh, H., Zegelin, S., Hughes, D., van Gorsel, E., Kitchen, M., Vana, M., Hõrrak, U., Mirme, S., Mirme, A., Sevanto, S., Twining, J., and Tadros, C.: Formation and characteristics of ions and charged aerosol particles in a native Australian Eucalypt forest, Atmos. Chem. Phys., 8, 129-139, 2008, http://www.atmos-chem-phys.net/8/129/2008/.

Tammet, H.: The aspiration method for the Determination of Atmospheric-Ion Spectra, The Israel Program for Scientific Translations Jerusalem, National Science Foundation, Washington DC, USA, 200 pp., 1970.

Tammet, H.: Size and mobility of nanometer particles, clusters and ions, J. Aerosol Sci., 26, 459-475, 1995.

Tammet, H., Hõrrak, U., and Kulmala, M.: Negatively charged nanoparticles produced by splashing of water, Atmos. Chem. Phys., 9, 357-367, 2009,

http://www.atmos-chem-phys.net/9/357/2009/.

Twohy, C., Clement, C., Gandrud, B., Weinheimer, A., Campos, T., Baumgardner, D., Brune, W., Faloona, I., Sachse, G., Vay, S., et al.: Deep convection as a source of new particles in the midlatitude upper troposphere, J. Geophys. Res., 107, 4560, doi: 10.1029/2001JD000323, 2002.

Vartiainen, E., Kulmala, M., Ehn, M., Hirsikko, A., Junninen, H., Petaejae, T., Sogacheva, L., Kuokka, S., Hillamo, R., Skorokhod, 
A., et al.: Ion and particle number concentrations and size distributions along the Trans-Siberian railroad, Boreal Env. Res., 12, 375-396, 2007.

Venzac, H., Sellegri, K., and Laj, P.: Nucleation events detected at the high latitude site of the Puy de Dome Research Station, France, Boreal Env. Res., 12, 345-359, 2007.

Wang, M. and Penner, J. E.: Aerosol indirect forcing in a global model with particle nucleation, Atmos. Chem. Phys., 9, 239-260, 2009, http://www.atmos-chem-phys.net/9/239/2009/.

Weigelt, A., Hermann, M., van Velthoven, P., Brenninkmeijer, C., Schlaf, G., Zahn, A., and Wiedensohler, A.: Influence of clouds on aerosol particle number concentrations in the upper troposphere, J. Geophys. Res., 114, D01204, doi:10.1029/ 2008JD009805, 2009.
Weinzierl, B., Petzold, A., Esselborn, M., Wirth, M., Rasp, K., Kandler, K., Schutz, L., Koepke, P., and Fiebig, M.: Airborne measurements of dust layer properties, particle size distribution and mixing state of Saharan dust during SAMUM 2006, Tellus B, 61, 96-117, 2009.

Young, L., Benson, D., Montanaro, W., Lee, S., Pan, L., Rogers, D., Jensen, J., Stith, J., Davis, C., Campos, T., et al.: Enhanced new particle formation observed in the northern midlatitude tropopause region, J. Geophys. Res., 112, doi:10.1029/ 2006JD008109, 2007.

Yu, F., Wang, Z., Luo, G., and Turco, R.: Ion-mediated nucleation as an important global source of tropospheric aerosols, Atmos. Chem. Phys., 8, 2537-2554, 2008, http://www.atmos-chem-phys.net/8/2537/2008/. 